\title{
The Labor Movements in the United States and the United Kingdom
}

\author{
Hany H. Makhlouf, Ph. D. ${ }^{\text {* }}$ \\ a Professor, School of Business and Public Administration, University of the District of Columbia, Washington, D. C. \\ *Corresponding author's email address: hmakhlouf@udc.edu
}

\section{A R T I C L E I N F O}

Received: 15-02-2016

Accepted: 10-03-2016

Available online: 25-04-2016

\section{Keywords:}

The Combination Acts, Knights of Labor, American Federation of Labor (AFL), Congress of Industrial Organizations (CIO), Closed shop.

\section{JEL Classification:}

\begin{abstract}
A B S T R A C T
The rise of the labor movements in the United Kingdom in the 17th century and in the United States in the 19th century, their growth through most of the 20th century, and their steady decline since the 1970s reflect several similarities and differences in their experiences, strategies, tactics, and goals. Both movements faced many early challenges that threatened their survival, and went through growth periods, followed by the current decline phase in which they are struggling to prove their worth and relevance in changing economies and new labor market realities. This article examines the similarities and differences in these labor movements' experiences, and in their past and current environments. It argues that labor unions are not likely to face the destiny of the dinosaurs, but they may have to continue to evolve, adjust, and innovate to stop their decline and appeal to a changing labor force. Their bread and butter focus, however, is likely to remain as the core of their existence.
\end{abstract}

(C) 2016 The Authors. This is an open access article under the terms of the Creative Commons Attribution License 4.0, which allows use, distribution and reproduction in any medium, provided the original work is properly cited.

DOI: http://dx.doi.org/10.18533/rss.v1i4.28

\subsection{Introduction}

Media reports and scholarly articles have commented for many years on the decline of labor union power and influence, and the shrinking size of their membership relative to the overall number of waged and salaried workers in the advanced economies of Europe and North America, including the United States and the United Kingdom. The U.S. Bureau of Labor Statistics reports that union membership rate in the United States has declined from close to 25 percent in 1973 to 11.1 percent in 2014. Similarly the British Advisory, Conciliation, and Arbitration Service (ACAS), which is an independent body of the British government, also indicates that "unions in virtually all developed economies have lost membership in recent decades, but the decline (in labor union density) has been especially sharp in Britain. Union density stood at $27 \%$ in 2010, compared to $30 \%$ in 2000 , and $50 \%$ t in 1980" (p. 2). This decline would have been even more dramatic were it not for the relatively steady membership in public employee unions in both of the United States and the United Kingdom.

This article examines the past and current union environments, as well as the rise and decline of unionism from the pre-Industrial Revolution period to the present, focusing primarily on the United States and the United Kingdom. It needs to be emphasized at the outset, however, that unions are not likely to become extinct in the foreseeable future. In spite of the challenges they have encountered in recent decades, their overall impact in protecting workers' rights and earnings cannot be dismissed. Their effectiveness, despite recent decline and multiple challenges, is still reflected in the gap that exists in the average earnings of unionized versus 
nonunionized workers. According to Bureau of Labor statistics, the average weekly earnings of unionized workers in the United States reached $\$ 970$ in 2014 as compared to $\$ 763$ for nonunion workers. Also in a study for the United Kingdom's National Institute of Economic and Social Research, Alex Bryson (2014, July 1), has found evidence of "a union membership wage premium of between 10 percent and 15 percent" (p. 4). In addition, Bryson (2014, July 1) points to the fringe benefits that union members get such as retirement benefits and paid holidays that are enjoyed due to union negotiations (p. 4).

\section{$2.0 \quad$ Historical experiences}

The rise of unions, as we know them, is often traced back to the start of the Industrial Revolution in England in the $17^{\text {th }}$ century and in the United States in the $19^{\text {th }}$ century, and the accompanying expansion of the factory system, which has transformed the economies of both countries from being mostly agrarian and small business oriented to becoming industrial, with mass production replacing old production technologies. However, some guilds and other union-like groups, existed and spoke in behalf of disgruntled workers even before the Industrial Revolution. Some workers' protests for example, were recorded as early as 1636 in the state of Maine, as a group of fishermen collectively protested their low wages (A Beginner's Guide to the History of Unions, $\mathrm{n}$.d.).

Some guilds, like the Society of Cordwainers (shoemakers) represented some craft workers in the United States as early as 1794. French (2003) reports that the Society of Cordwainers attempted in 1799 to bargain with employers but this attempt "resulted first in the employers locking their shops to keep out the workers... and then in a negotiated settlement" (p. 31) However, the employers later took the union to court that declared the union guilty of a criminal conspiracy to pressure the employers to increase wages (p. 31).

In the aftermath of the Industrial Revolution and the expansion of the factory system, first in The United Kingdom and later in the United States, workers found themselves for the first time having to commute long distances to their new places of work where they had to learn new skills. In the factory set up, a large number of workers had to work under the same roof and subjected to close supervision and new disciplinary rules. This work environment was conducive to the expansion of unionism. Under that system, factories also became increasingly mechanized and, thus, requiring large capital and abundant space to get started. Accordingly, it became far more difficult, if not impossible, for the average worker to transition from being a wage earner into employer who can decide on what and how much to produce; hence, the gap between the workers and their new employers became much wider, compared to the time when non-farm products were mostly "made- to- order" in home-based workshops or other kinds of small set-ups, each having one or a few journeymen and apprentices working with simple tools directly under a master craftsman. Those small workshops, whether they were or were not home-based, did not require much capital or any hierarchical structures. They also did not have much by way of division of labor or multiple layers of authority (Mokyr, 2001, January I, p. 4).

Thus, the factory work environment had a psychological impact on workers. In addition, workers had to acquire new work skills and follow new rules and procedures.. In contrast to the factory system, Mokyr (2001, January 1) indicates that "workers (in the old home-based system) could choose essentially any point on the leisureincome trade-off; this freedom of choice was much reduced once workers had to submit to the factory regime. Even a combination of higher wage with lower leisure ....could be welfare reducing if it became an all or nothing choice....In terms of the physical environment, the shift to noisy, unpleasant, and dangerous locations...reduced workers' well-being" (p. 8-9).

Furthermore, the new employers, who could be described as industrial capitalists, were more interested in profitability, productivity, and cost reduction than in addressing workers' needs. Thus, describing early factory conditions in the United Kingdom that may have promoted unionization, Striking Women (n. d.) indicates that "the conditions in these new factories were often harsh, with men, women and even children forced to work long hours for very low wages" (Striking Women, n. d., p. 3).

In their early years, unions as they resorted to work stoppages to bring about change, were not understood or broadly accepted even by some of the workers themselves, who could have been potential dues-paying members. Instead, they were met with a great deal of suspicion and hostility by employers, the government, the press, the courts, and the general public, both in the United Kingdom and the United States. Explaining the difficulty faced in getting organized in those early years, the Beginner's Guide to the History of Unions in the United Kingdom (2015) points out that during the dawn of unionism employers and land-owners had a lot of power to deter unionism. They also were more respected in society than the low wage earners and their associations. For example, "one of the largest groups of workers in Britain was (the) agricultural workers who repeatedly tried to establish union organizations. They too were attacked by bosses in 1872 and $74 \ldots$ Evictions of 
farm labourers and their families from their cottages which was tied to their employment were a powerful deterrent to union organization" (p.4).

According to Reynolds (2009), the hostility that early American unions and their leaders faced was, however, partly their own fault. He indicates that in those early years "there was no prevailing ideology of working-class solidarity, and unions were far from respectable; in fact, they had a well-earned reputation for being antisocial, even criminal...(Some) unionists engaged in intimidation, threats, vandalism, and violence, especially against uncooperative workers." (p. 3). Regardless of this characterization of unions and their leaders, the society's strong belief in private property rights, which meant that property owners had an absolute power to run it, contributed to the inevitable gap in attitudes and diversion of interests, One should add that the novelty of the idea that workers can challenge managerial decisions, engage in strikes, and have demands of their own, by itself, contributed to the employers' negatives reaction to unionism. This applies to both the United States and the United Kingdom.

From the legal standpoint, unions had no legal status or legal protection in their early years. Existing laws, including anti-monopoly laws were used by the courts to restrain their growth or even to get rid of them. In the United Kingdom, the government sought to curb unions by passing the Combination Acts of 1799 and 1800, which made strikes illegal, and were also interpreted to mean that unions were themselves illegal combinations. Those laws made striking a crime punishable by three month imprisonment or two months with hard labor but they were finally repealed in 1824 and 1825 due to public protests, only to be replaced by new anti- union measures in the 1830s, following some labor unrest. It was not until the passing of the Trade Union Act in 1871 that unions in the United Kingdom acquired a legal status, and engaging in picketing during a strike became also legal in 1875 (Striking Women, n. d., p. 4).

French (2003) describes the change in U.S. government policies toward unions, stating that "the federal government attitude toward the labor movement gradually changed from opposition to neutrality and finally to support..." (p. 33). To some observers the support for unionism shifted again in the reverse direction, at least, to some degree, shortly after the end of the Second World War. After viewing unions as conspiracies in restraint of trade and after being subjected to the anti-monopoly Sherman Act, the Clayton Act was passed in 1914 and the Norris -LaGuardia Act in 1932. These acts gave unions some relief from court-ordered strike injunctions. The Norris LaGuardia Act also made the yellow-dog contracts, in which workers pledged not to join a union as a condition of employment, unenforceable.

Due to the importance of railways in inter-state transportation and trade, the Railway Labor Act was passed in 1926, allowing workers in that sector to join unions and bargain collectively with their employers. It also provided for arbitration of disputes before strikes were declared. The National Industrial Recovery Act of 1933, that aimed at economic revival in the United States after the Great Depression of 1929, went further by essentially giving all workers, in the private sector, the right to join unions of their own choosing and bargain collectively with their employers. This gradual acceptance of unionism eventually led to the National Labor Relations Act of 1935 (the Wagner Act), which gave workers and their unions more protection. This act was, however, amended in 1947 (by the Taft-Hartley Act) to add some restraints on union activities. One of its contributions was the establishment of the Federal Mediation and Conciliation Service as a neutral body that may get involved in solving some labor-management disputes. The 1947 version of the National Labor Relations Act (that is also known as the Taft-Hartley Act), and the state Right-to-Work laws of 1946, were seen by the labor movement as the beginning of a new wave anti-union government policies and legislation. The Right-toWork laws, that have been enacted in 22 southern and western state's were particularly, condemned by unions because they made it illegal to require workers to join unions or pay union dues as a condition of employment (Griffin, 2013, p. 384).

The delayed and gradual approach in the U.S. federal government's recognition of the right of all workers in the private sector to join unions and bargain collectively with their employers restrained the growth of unions until the 1930s. Many local unions were established before but they lacked full legal backing, and attempts were made to have some national labor organizations, but those organizations often had a high failure rate. One of the most successful of those, however, was the Knights of Labor that intended to become an umbrella organization for craft locals. It was started in Philadelphia, Pennsylvania, in 1864 at first as a secret organization, but its membership remained limited until it dropped its secrecy. Its membership reached its highest level of 700,000 by the mid-1880s before it started to have internal problems. One of the distinguishing features of the Knights of Labor was its desire to transform the structure of the American economy into workers' owned cooperatives. It also stood against the wage system of pay, and considered wages to be a cause of man's degradation, but it still advocated higher pay for its members. One of its problems is that it did not know how to bring about the changes that it advocated or live up to its slogan (an injury to one is the concern of all) as evidenced by its 
refusal to accept Chinese workers. It also started to support unpopular strikes and accept industrial unions (non-craft unions) as members, which created internal disagreements. As a result, some pro-craft union leaders walked out of the Knights of Labor in 1886 to establish a competing organization, the American Federation of Labor (AFL) to be exclusively for craft unions and to concentrate on what it considered to be the most important issue for workers-- namely, bread and butter issues (Kennedy, 2001; American Federation of Labor, 2014).

Samuel Gompers, a cigar-maker, who immigrated to the United States from the United Kingdom, was the main founder and the first president of AFL. It is commonly believed that he was influenced in his views toward unionism by his and his father's experience in the British cigar-makers' local union. He, therefore, steered the AFL away from the Knights of Labor political and economic ideologies, and help in re-directing the labor movement exclusively towards ways to improve the economic lot of workers (Yellowitz, 1989, July).

Nevertheless, what happened to Knights of Labor ended up happening to the AFL, as Internal conflicts and disagreements led some pro-industrial union leaders, who wanted the AFL to change its membership policy and accept all types of unions, not just the craft type. This move resulted in the establishment of a competing labor federation in 1935-1937: The Congress of Industrial Organizations (CIO). After an initial period, in which the two federations followed different strategies, they eventually started to look alike. Both started to accept all types of labor unions as full members, the craft and the industrial. This reason and a growing body of external challenges, like the Right-to- work laws and some of the provisions in the amended National Labor Relations Act, brought about a merger of the AFL and the CIO in 1955 to become one federation to represent all affiliated unions, regardless of type: the AFL-CIO (Loomis, 2011, December 5).

\subsection{The role of strikes and impact of governmental constraints}

Strikes have been the unions' primary instrument to put pressure on employers in order to get them to accept their demands. Traditionally, they have been the most lethal weapon or instrument for unions to use for attaining better settlements with the employers. In the early years of unionism, employers, both in the United States and the United Kingdom, reacted strongly to strikes. Some resorted to the courts to issue anti-strike injunctions and order workers to go back to work or risk losing their jobs. Some employers hired strike breakers in order to keep the business or the factory running. Some also tried to intimidate the workers with the threat to move the business to another location. Violent confrontations sometimes resulted in loss of life and property, as happened in the Carnegie steel plant in Homestead in Pennsylvania in 1892. That strike and management's reaction to bust the union once and for all ended in a bloody battle in which several lives were lost (Johnson, 2008, p. 1-7).

In the United Kingdom, according to Osmont (2003, October 11), "383 disputes had been recorded between 1717 and 1800, but the real figure is undeterminable" (p. 1). In the more recent history, frequent and lengthy strikes through the first seven decades of the $20^{\text {th }}$ century, resulted in a great deal of public dissatisfaction with unionism in the United Kingdom. Striking Women's, (n. d.) on the role of trade unions in the UK indicates that in the 1970 s "21.9 million working days each year were lost to strike action, rising to 28.47 million in the winter of discontent in 1979" (p. 7). The frequency of strikes, and the impact of such strikes on the country's competitiveness in an increasingly globalizing economy, is believed to have caused the downfall of the Labor government of Jim Callaghan, and the election of the Conservative government of Margaret Thatcher in 1979 (Striking Women, n. d., p. 7).

Striking Women, (n. d.) reported that "Margaret Thatcher was determined to win the battle against the strikers whom she termed the enemy within" (p. 8). Thus, she introduced five major pieces of legislation during the 1979-1990 time span that made it far more difficult for workers to legally strike or establish new unions. These new laws, among other things, banned the Closed Shop that requires union membership before a worker is hired, and the Union Shop that requires joining the union after the worker is hired. As a result of these new laws and the unfriendly political environment that led to their creation, union membership in the United Kingdom dropped from 13 million in 1979 to 7.5 million by 2000. It is important to note also that the Labor government, that succeeded the Conservative government, did not change the Thatcher anti-union legislation (Striking Women, n. d., p. 8-9). Furthermore, another restrictive bill was introduced in the House of Commons in 2015. It requires unions to notify employers of pending strikes, at least 14 days in advance. It also requires that a minimum of 50 percent of union members to be present and vote in favor of striking if a strike can legally take place. For public employee unions, the bill requires only 40 percent presence for strike approval votes. Essentially, this bill aims at helping employers to plan counter-strategies to minimize the impact of a pending work stoppage, and also makes striking more difficult and less effective (The Economist, 2015, July 16). 
Regardless of the legal constraints and limitations, some observers on the labor scene believe that strikes have lost a great deal of their effectiveness due to globalization and recent advances in production and information technologies. Aronowitz (2005, March) observes that, as a result of this reality, some union leadership nowadays actively discourage members from engaging in strikes" (p. 273). He also argues that strikes have become less appealing because of the current weak stand of unions, and further observes that union weakness, at least in the United States, has brought about a "virtual disappearance of the strike weapon in most industries and sectors. As a result, in many instances, collective bargaining has become collective begging" (p. 279).

\subsection{Union growth before the recent decline in membership and power}

As the general public began to accept the concept of collective bargaining, the political and legal environments started to show greater sympathy and support for unionism, and unions gradually grew in number and density, both in the United States and the United Kingdom. Some unions flirted with some leftist or socialist political ideologies, and engaged, to some degree, in political activities in an effort to become more influential. This was particularly the case in the United Kingdom where unions were involved in the emergence of the Labor Party with which they, in fact, continue to have some, though diminishing, relationship. The 1870s witnessed a significant growth of British unions. Such growth meant more work stoppages that antagonized employers and some in the government and the general public (Sano and Williamson, 2008, p. 480).

\subsection{The decline in support for unionism in the 1970s and after}

Complex issues usually have multiple causes. The decline of support for unions that accelerated since the 1970s and 1980s is one of such issues. One frequently repeated factor is globalization, which increased competition worldwide, and facilitated the movement of manufacturing and some services to other countries in order to lower costs or increase overall efficiency. This is definitely an important factor, but is it the only one? Not so. For example, globalization was not the reason behind the workers' vote against the establishment of a union at the VW plant in Chattanooga, Tenn. in 2014. The union faced a defeat by a 712 to 626 vote. Thus, one has to consider other factors in addition to globalization for the weakening of union support. Margaret Thatcher did it, as mentioned earlier, by initiating a set of laws, aiming at reducing the power of unions and making them less effective.

Logan (2006) attributes to the emergence of a union avoidance industry, composed of lawyers and consultants that advise companies on legal ways to avoid unionization. He indicates that "this (union avoidance) industry has not only enabled employers to resist unionization, it has also allowed them to undermine union strength, or unload existing unions" (p. 651). An AFL-CIO official alluded to the influence of that industry after the union vote defeat at Chattanooga by stating that "outside interference affected the outcome of the vote. Unfortunately, politically motivated third parties threatened the economic future of this facility" (Boudette, The Wall Street Journal, Feb. 15, 2014). Another factor that Margalioth (1998) writes about is the return to individualism in the American working environment and the reduced emphasis by younger workers on money and job security which have traditionally been most important to unions and their membership (p. 124). Along with these factors, one can mention the perception among some workers of union corruption and misuse of union fund, which also affects the image that members of the public' correctly or incorrectly, associates with unions.

\subsection{Practical implications of the study}

This study reflects some of the similarities and differences between the experiences of the labor movements in the Unites States and the United Kingdom. It, thus, adds to the understanding of international managers, who may be active in both economies, of the ways organized labor operates in both economies, and how union motives and negotiation tactics may impact the management process, within the limits of both countries' laws and labor regulations. This study is also relevant to students of international business relations and comparative collective bargaining law since it attempts to increase awareness of unionism in two of the largest economies that are linked by culture and trade as well as investments by their multinational companies.

\subsection{Conclusion}

Union membership in the United States and the United Kingdom has declined over several decades. This has coincided with the expanding wave of globalization and the resulting shift of a significant part of the world manufacturing capacity from the old industrialized countries to the emerging economies and developing world. This is why many observers, pundits and politicians associate the decline in unionization just to expansion of globalization and the need to be nationally competitive through moderation of wage demands. The reality is that other factors have also impacted unionization, not only in the United States and the United Kingdom, but in 
other OECD countries as well. Unions must, therefore adopt some new strategies that make them more appealing in the $21^{\text {st }}$ century including helping management with new ways to raise productivity, efficiency, innovation and the value added in the production and marketing processes. International comparisons in regard to efficiency, innovation, quality, and productivity cannot be ignored in the collective bargaining process.

\section{References}

"A Beginner's Guide to the History of Unions". Retrieved from: http://www.grahamstevenson,me.uk/index.php?option=com_content\&view=article\&id $=6 \ldots$

American Federation of Labor (2014)." Organized Labor". U. S. History. Retrieved from: http://www.ushistory.org/us/37d.asp.

Boudette, N. (2014, February 15). Union Suffers Big Loss at Tennessee VW Plant. The Wall Street Journal. Retrieved from: http://wsj.com/articles/SB100014240527023044341045793382541226307368.

Bryson, A. (2014, July 1). "Union Wage Effects: What are the Economic Implications of Union Wage Bargaining for Workers, Firms, and Society?". National Institute of Economic and Social Research, UK. IZA World of Labor, 1-8.

Bureau of Labor Statistics (2014). Union Membership Summary. Economic News Release. Retrieved from http://bls.gov/nfws.release/union2.nr0.htm.

French, W. (2003). Human Resources Management. 5th Edition. Boston and New York: Houghton Mifflin Company.

Griffin, R. (2013). Management. 11th Edition. Cengage Learning, p. 384.

Kennedy, R. C. (2001). "On This Day". New York Times. Retrieved from: https://www.nytimes.com/learning/general/onthisday/harp/0424.html.

Logan, J. (2009, December). "The Union Avoidance industry in the United States". British Journal of Industrial Relations, 44 (4). P. 651-675. http://dx.doi.org/10.1111/j.1467-8543.2006.00518.x

Loomis, E. (2011, December 5). "The Day in Labor History: December 5, 1955". Retrieved from: http://lawyersgunsmoneyblog.com/2011/12/this-day-in-labor-history-december-5- 1955.

Marglioth, S. R. (1998). "The Significance of Worker Attitudes: Individualism as a Cause for Labor's Decline". Hofstra Labor and Employment Law Journal. 16(1), 133-150.

Mokyr, J. (200l, January 1). "The Rise and Fall of the Factory System: Technology, firms, and Households since the Industrial Revolution". Paper Prepared for the Carnegie-Rochester Conference on Macroeconomics, Pittsburgh, Nov. 17-19, 2000.

Osmont, G. (2003, October 11). "The Combination Acts, 1799-1800". Retrieved from: http://anglais.uparis10.fr/spip.php?article92.

Reynolds, M. (2009, July 17). "A History of Labor Unions from Colonial Times to 2009". MISES Institute. Retrieved from: https://mises.org/library/history-labor-unions-colonal-times- 2009.

Sano, J., and J. Williamson (2008). "Factors Affecting Union Decline in 18 OECD Countries and their Implications for Labor Movement Reform". International Journal of Comparative Sociology. Sage Publication, 49(6), 479500. http://dx.doi.org/10.1177/0020715208098614

Striking Women (n.d.). "Claiming Rights: Role of Trade Unions in the United Kingdom". Retrieved from: https://www,striking-women.org/module/rights-and- responsibilities/claiming-rights-role-tr...

The Economist (2015, July 16). "Why Is Britain Making It Harder to Strike". Retrieved from: http://economist.com/blogs/freeexchange/2015/07/trade/unions

Wright C. F. (2011, September). "What Role for Trade Unions in Future Workplace Relations?" ACAS Future of Workplace Relations Discussion Paper Series, 1-10.

Yellowitz, I. (1989, July)." Samuel Gompers: A Half Century in Labor's Front Rank". Monthly Labor Review, p. 27 33. 